\title{
Studies on the absorption and retention of calcium and phosphorus by young and mature Ca-deficient sheep
}

\author{
BY G. D. BRAITHWAITE \\ National Institute for Research in Dairying, \\ Shinfield, Reading $R G_{2}{ }_{9} A T$ \\ (Received 20 fanuary 1975 - Accepted I4 March 1975)
}

\begin{abstract}
I. A combination of a mineral balance and a radioactive technique has been used to study the effects of increased levels of dietary calcium and phosphorus on the $\mathrm{Ca}$ and $\mathrm{P}$ metabolism of young and mature wether sheep previously made $\mathrm{Ca}$-deficient.

2. Ca absorption was directly related to $\mathrm{Ca}$ intake until an absorption maximum was reached. Young animals absorbed dietary $\mathrm{Ca}$ more efficiently than mature animals and had a much higher maximum rate of absorption. Apparent $\mathrm{P}$ absorption was directly related to $\mathrm{P}$ intake and maximum $P$ absorption was also higher for the young animals.

3. Excretion of $\mathrm{Ca}$ in the urine and into the intestine was not altered by changes in $\mathrm{Ca}$ intake. Excretion of $P$ in the urine, however, varied considerably and it is suggested that this
\end{abstract} process may be largely responsible for $P$ homoeostasis.

4. $\mathrm{Ca}$ retention was directly related to $\mathrm{Ca}$ absorption. Maximum retention was considerably higher for the young animals than for the mature animals and occurred for each group of animals at exactly the same dietary intake as maximum $\mathrm{Ca}$ absorption.

5. $\mathrm{Ca}$ and $\mathrm{P}$ were retained in a constant ratio of $I \cdot 25: I$ and the results suggested that $P$ retention was controlled by the rate of $\mathrm{Ca}$ retention.

6. Bone turnover was higher for the young than for the mature animals. Animals mobilized skeletal $\mathrm{Ca}$ when receiving the $\mathrm{Ca}$-deficient diet and replaced their $\mathrm{Ca}$ losses when the dietary $\mathrm{Ca}$ was plentiful by changing the relative rates of bone resorption and bone accretion. Although bone resorption was mainly responsible for $\mathrm{Ca}$ homoeostasis, bone accretion appeared to play some part in the young animals.

7. Maximum retention of Ca occurred just as the rate of bone resorption became zero and was equal to the rate of bone accretion. The lower maximum retention of $\mathrm{Ca}$ for mature animals was due to a lower rate of bone accretion.

8. Results suggested that when bone resorption ceased, $\mathrm{Ca}$ absorption was regulated by homoeostatic mechanisms at a level just sufficient to maintain maximum retention, and that the maximum rates of absorption measured may not have been true maximum rates.

9. The consequences of a relationship between bone accretion and maximum Ca retention are discussed with reference to older, pregnant and lactating animals.

In calculating the dietary calcium requirements of sheep, the authors of The Nutrient Requirements of Farm Livestock (Agricultural Research Council, 1965) make the assumption that the efficiency of absorption of $\mathrm{Ca}$ decreases with age. It has recently been shown that when growth of nearly mature wethers is stimulated by treatment with oestrogen or growth hormone, the efficiency of absorption of $\mathrm{Ca}$ is also increased (Braithwaite, Glascock \& Riazuddin, 1972; Braithwaite, 1975). This suggests that the decrease in the efficiency of absorption with increasing age may only reflect decreased $\mathrm{Ca}$ requirements.

Certainly young animals with high $\mathrm{Ca}$ requirements absorb $\mathrm{Ca}$ at a higher rate and with a greater efficiency than mature animals with low requirements (Braithwaite \& Riazuddin, 1971). Furthermore, when requirements of mature animals are increased 
Table I. Daily intake for dietary ingredients of the low-calcium basal diet for sheep, and the $C a$ and phosphorus contents of these ingredients

\begin{tabular}{|c|c|c|c|c|c|}
\hline Ingredient & $\begin{array}{c}\text { Amount } \\
\text { (g/kg } \\
\text { body-wt) }\end{array}$ & $\begin{array}{l}\text { Ca content } \\
(\mathrm{mg} / \mathrm{g})\end{array}$ & $\begin{array}{c}\text { Total Ca } \\
\text { (mg/kg } \\
\text { body-wt) }\end{array}$ & $\begin{array}{l}\text { P content } \\
(\mathrm{mg} / \mathrm{g})\end{array}$ & $\begin{array}{c}\text { Total P } \\
(\mathrm{mg} / \mathrm{kg} \\
\text { body-wt) }\end{array}$ \\
\hline Straw & 5 & $3 \cdot 4$ & $17 \cdot 0$ & 0.8 & $4 \cdot 0$ \\
\hline Barley & 5 & 0.7 & $3 \cdot 5$ & $4 \cdot I$ & $20 \cdot 5$ \\
\hline Flaked maize & $2 \cdot 5$ & 0.03 & $0 . \mathrm{I}$ & $\mathrm{r} \cdot 5$ & 377 \\
\hline Bran & $I \cdot 25$ & 0.4 & 0.5 & $12 \cdot 7$ & $15 \cdot 9$ \\
\hline Linseed-oil cake & 0.5 & 3.1 & $2 \cdot 8$ & $8 \cdot 4$ & $4 \cdot 2$ \\
\hline Vitamin mixture* & 0.07 & 15.7 & $I \cdot I$ & $2 \cdot 2$ & 0.2 \\
\hline Whole diet & & & 25.0 & & $48 \cdot 5$ \\
\hline
\end{tabular}

* Beta Vitamin No. 3 a (Cooper Nutrition Products Ltd, Witham, Essex), to supply $37.5 \mu \mathrm{g}$ retinol equivalent and $0.775 \mu \mathrm{g}$ cholecalciferol/kg body-wt.

as in pregnancy and lactation (Braithwaite, Glascock \& Riazuddin, I969, 1970) or after periods of $\mathrm{Ca}$ deficiency (Braithwaite, 1974) both the amount of $\mathrm{Ca}$ absorbed and the efficiency of absorption are increased.

The present studies were undertaken to compare young and mature animals, previously made Ca-deficient, in their ability to absorb and retain $\mathrm{Ca}$.

\section{EXPERIMENTAL}

Animals, housing and diet. Eight Dorset Horn wethers were used. Four were 5month-old growing animals weighing $25-35 \mathrm{~kg}$ and four were 5 -year-old mature animals weighing $80-90 \mathrm{~kg}$. They were housed in metabolism cages designed for the separate collection of urine and faeces, and had free access to distilled water.

It was calculated from results of Braithwaite $\&$ Riazuddin (197I) that sheep require $55 \mathrm{mg} \mathrm{Ca} / \mathrm{d}$ per $\mathrm{kg}$ body-weight to supply their maintenance requirements. In the present experiments animals were given a basal diet of straw and concentrates which contained less than half this amount of $\mathrm{Ca}$ (Table $\mathrm{I}$ ). This diet was supplemented, when necessary by the addition of calcium carbonate and disodium hydrogen orthophosphate, the orthophosphate was added to ensure that $\mathrm{Ca}$ retention was not limited by a lack of dietary phosphorus. The low-Ca diet contained an amount of $P$ adequate for maintenance (Agricultural Research Council, 1965) and at higher $\mathrm{Ca}$ intakes the dietary $\mathrm{Ca}: \mathrm{P}$ ratio was kept at about $\mathrm{I} \cdot 5$.

Experimental procedure. Mature animals were given the low-Ca diet for a period of 2 months before the start of the experiment to ensure that they were deficient in $\mathrm{Ca}$ (Braithwaite, 1974). The young animals, because they had additional growth requirements for $\mathrm{Ca}$ and became deficient more quickly, were given the diet for $\mathrm{I}$ month only. Ca metabolism was studied at $\mathrm{Ca}$ intakes fixed at approximately $20,5^{\circ}$, I00, 200, 300 and $500 \mathrm{mg} / \mathrm{d}$ per $\mathrm{kg}$ body-weight for the mature animals and at 20 , $100,300,400$ and $500 \mathrm{mg} / \mathrm{d}$ per $\mathrm{kg}$ body-weight for the young animals. The corresponding $\mathrm{P}$ intakes were 50,50,70, 150, 225 and $350 \mathrm{mg} / \mathrm{d}$ per $\mathrm{kg}$ body-weight for the mature animals and $60,60,200,300$ and $365 \mathrm{mg} / \mathrm{d}$ per $\mathrm{kg}$ body-weight for the 
young animals. Studies were done in a random manner, except those involving the low $\mathrm{Ca}$ intake which were done at the beginning and end of the experimental period. Each level of $\mathrm{Ca}$ intake was maintained for a period of $\mathrm{I} 2 \mathrm{~d}$ and kinetic measurements, lasting $7 \mathrm{~d}$, were started on the fifth day. Studies were done at monthly intervals; the animals were returned to the low-Ca basal diet for the $\mathrm{I} 8 \mathrm{~d}$ period between studies.

Experiments using young animals were confined to the period between 6 and II months of age, when changes in $\mathrm{Ca}$ metabolism are relatively small (Braithwaite $8 x$ Riazuddin, 1971). Increasing age has little effect on $\mathrm{Ca}$ metabolism in 5-year-old animals and it was possible to do a larger number of studies using these animals.

Methods. Ca kinetic studies were done using the method of Aubert \& Milhaud (1960) modified for use with sheep (Braithwaite et al. 1969; Braithwaite \& Riazuddin, r97I). The methods used for the determination of $\mathrm{Ca}$ contents and the measurement of the amount of radioactivity in samples of blood, faeces and urine have been described previously (Braithwaite et al. 1969). Total P content for ashed samples of food, faeces and urine was determined by the procedure of Fiske \& Subbarow (1925) modified for use with an AutoAnalyzer (Technicon Instruments Corporation, Basingstoke, Hants) (Technicon Instruments Corporation, 1967).

\section{RESULTS}

The effect of increased dietary intakes of $\mathrm{Ca}$ and $\mathrm{P}$ on the $\mathrm{Ca}$ and $\mathrm{P}$ metabolism of young and mature $\mathrm{Ca}$-deficient wethers are shown in Tables $\mathrm{2}$ and 3 . Ca metabolism was not significantly different at the beginning and end of the experimental period for either group of animals given the $\mathrm{Ca}$-deficient diet, indicating that period effects were negligible.

Absorption of $\mathrm{Ca}$ and $\mathrm{P}$. $\mathrm{Ca}$ absorption was low for both groups of animals, until the dietary $\mathrm{Ca}$ intake exceeded $20 \mathrm{mg} / \mathrm{d}$ per $\mathrm{kg}$ body-weight. The rate of absorption then increased directly with intake; the efficiency of absorption was greater for the young animals than for the mature animals (Fig. $\mathrm{x}$ ). There was a highly significant $(P<0.00 x)$ linear relationship between the rate of absorption and $\mathrm{Ca}$ intake for young animals between intakes of 100 and $400 \mathrm{mg} \mathrm{Ca} / \mathrm{d}$ per kg body-weight, and for mature animals between intakes of 50 and $200 \mathrm{mg} / \mathrm{d}$ per $\mathrm{kg}$ body-weight, and the following regression equations were calculated: young animals, $\mathrm{Ca}_{a}=8 \cdot 4+0 \cdot 2 \mathrm{Ca}_{i}$; mature animals, $\mathrm{Ca}_{a}=6 \cdot 0+0 \cdot 1 \mathrm{Ca}_{i}$; where $\mathrm{Ca}_{a}$ and $\mathrm{Ca}_{i}$ are $\mathrm{Ca}$ absorption and $\mathrm{Ca}$ intake (mg/d per kg body-weight) respectively.

Above dietary intakes of $200 \mathrm{mg} / \mathrm{d}$ per $\mathrm{kg}$ body-weight for mature animals and above $400 \mathrm{mg} / \mathrm{d}$ per kg body-weight for young animals, no significant increases in $\mathrm{Ca}$ absorption occurred. As a result of the greater efficiency of absorption by young animals and the higher intake reached before absorption became limited, their average maximum rate of absorption ( $87 \mathrm{mg} / \mathrm{d}$ per $\mathrm{kg}$ body-weight) was considerably greater than that for the mature animals $(28 \mathrm{mg} / \mathrm{d}$ per $\mathrm{kg}$ body-weight).

As endogenous secretion of $P$ into the intestine was not measured in these experiments, true rates for $\mathbf{P}$ absorption could not be calculated. Apparent $\mathbf{P}$ absorption ( $\mathrm{P}$ intake-total $\mathrm{P}$ in faeces), however, was directly related $(P<0.00 \mathrm{I})$ to $\mathrm{P}$ intake 


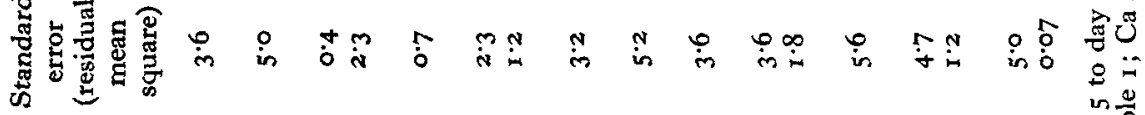

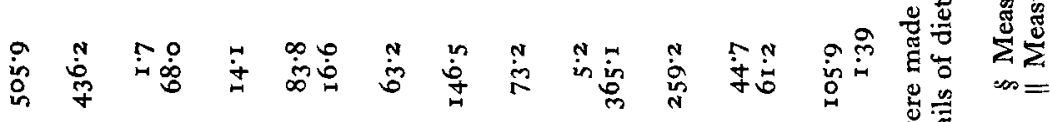

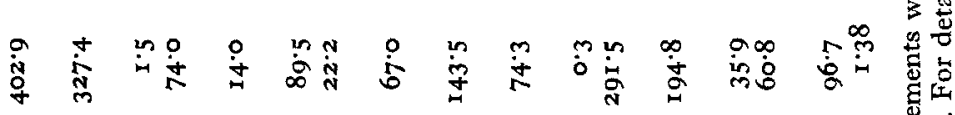

萡

竎

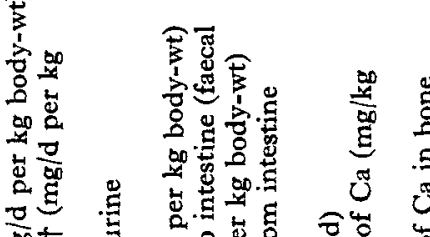

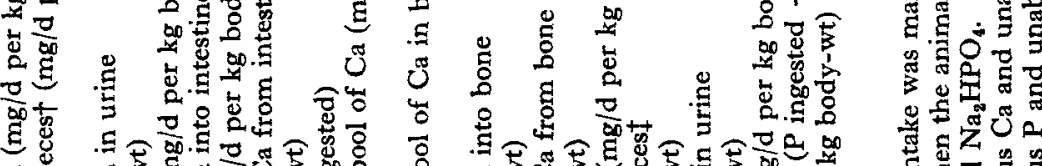

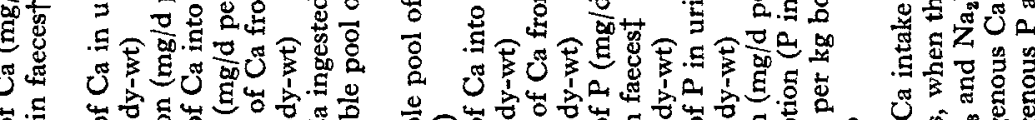

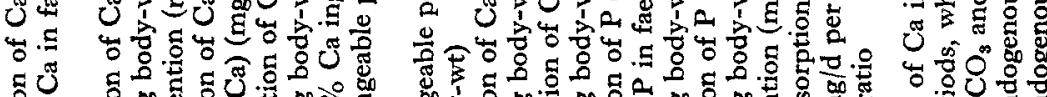

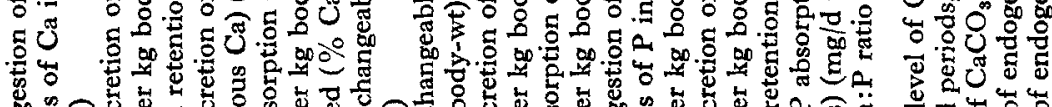

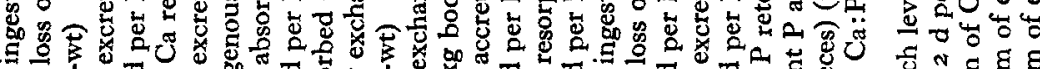

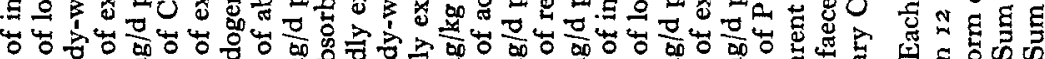

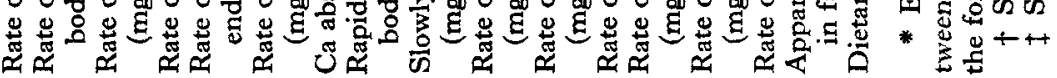


Vol. 34

Calcium metabolism in the sheep

焉

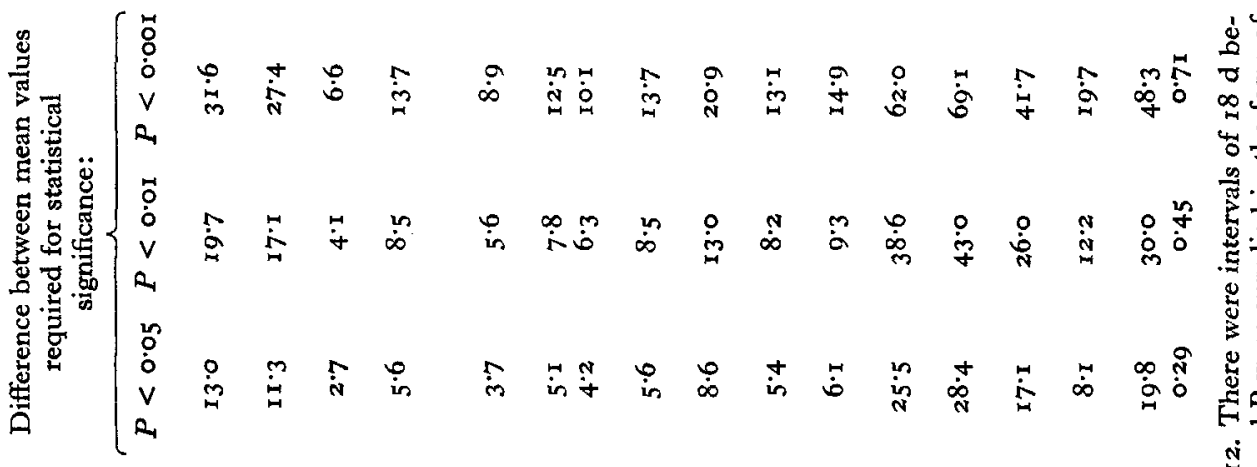

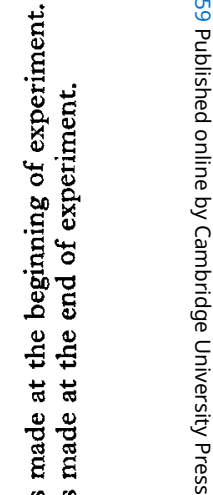

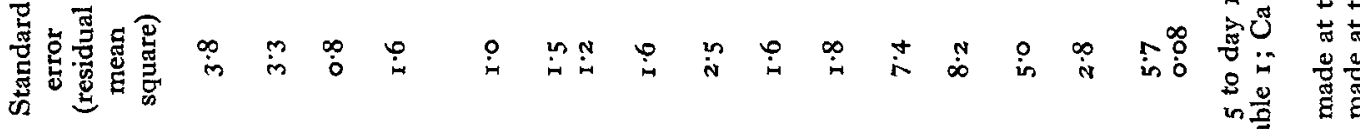

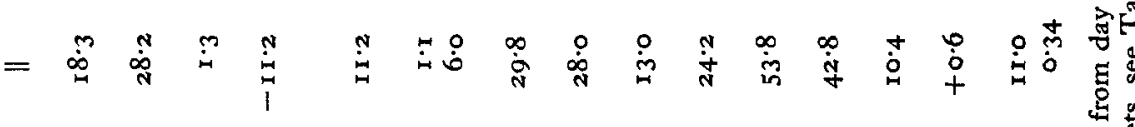

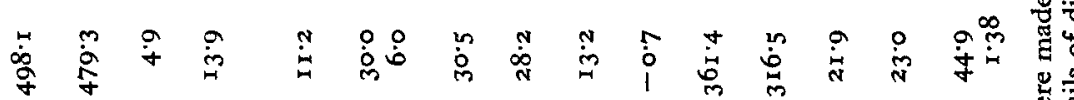

$\infty \cos =$

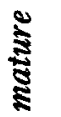

to

$\frac{8}{8}$



i⿱

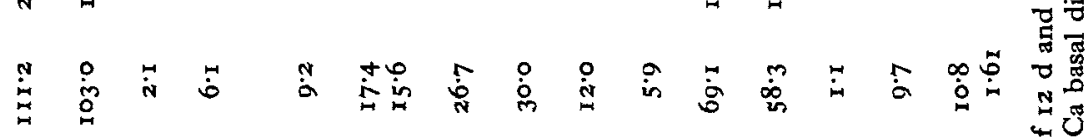

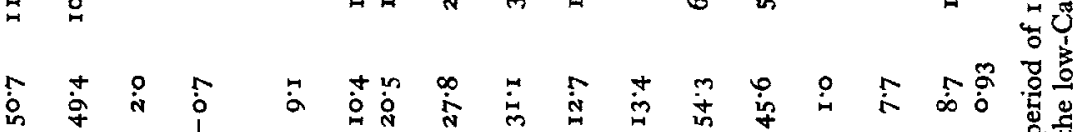

㻤安

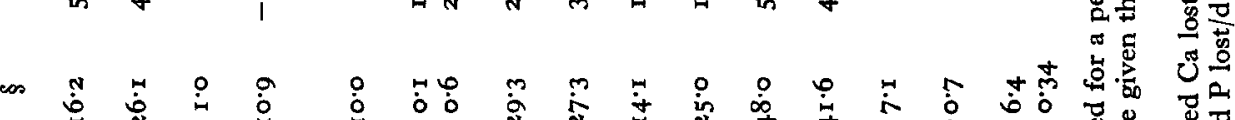

है

咅

$\approx$

ร

$\overleftarrow{\widetilde{E}}$

E

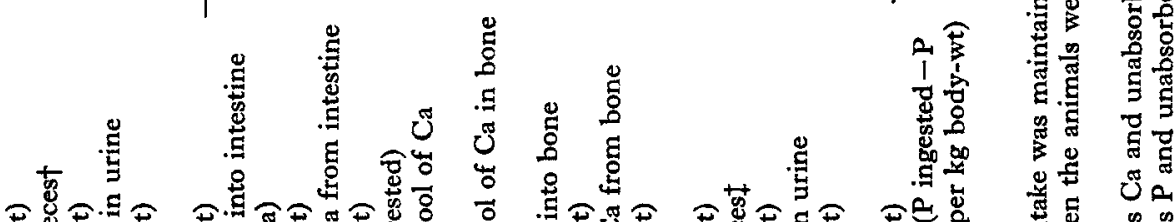

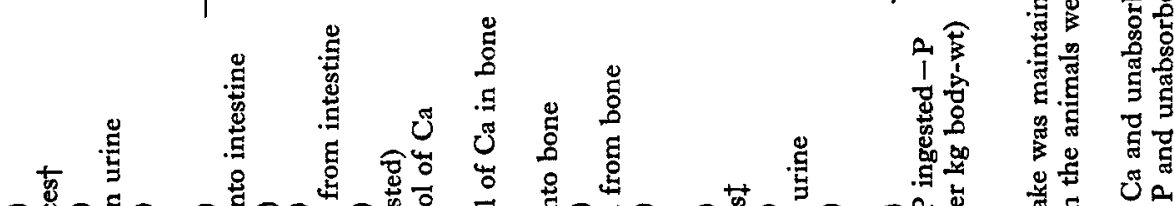

政

定

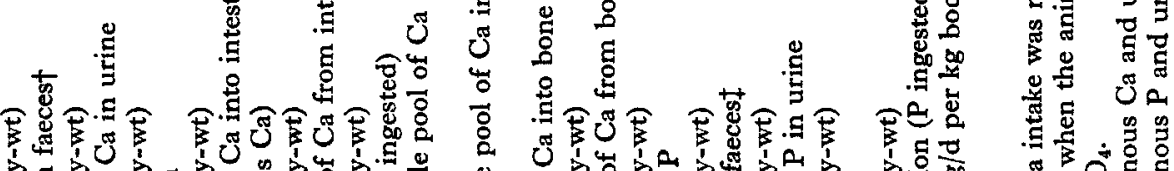

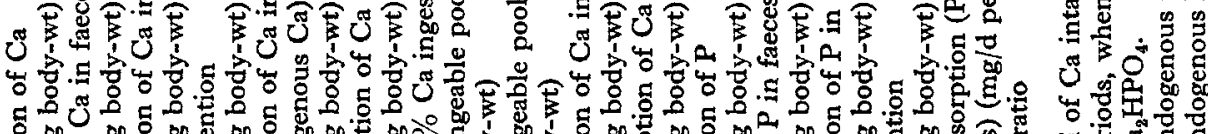

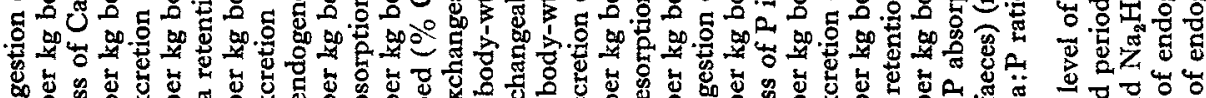

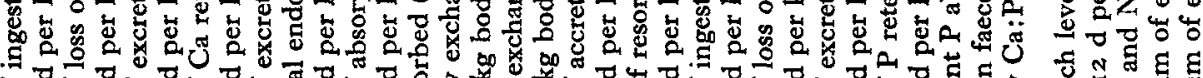

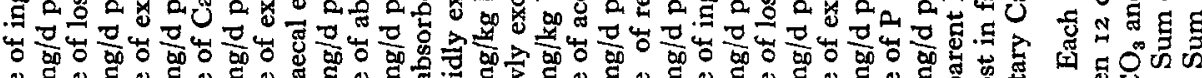

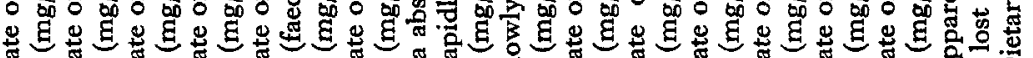

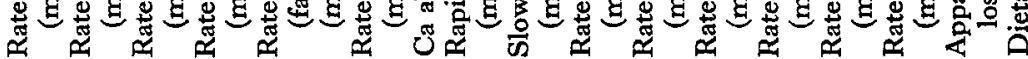




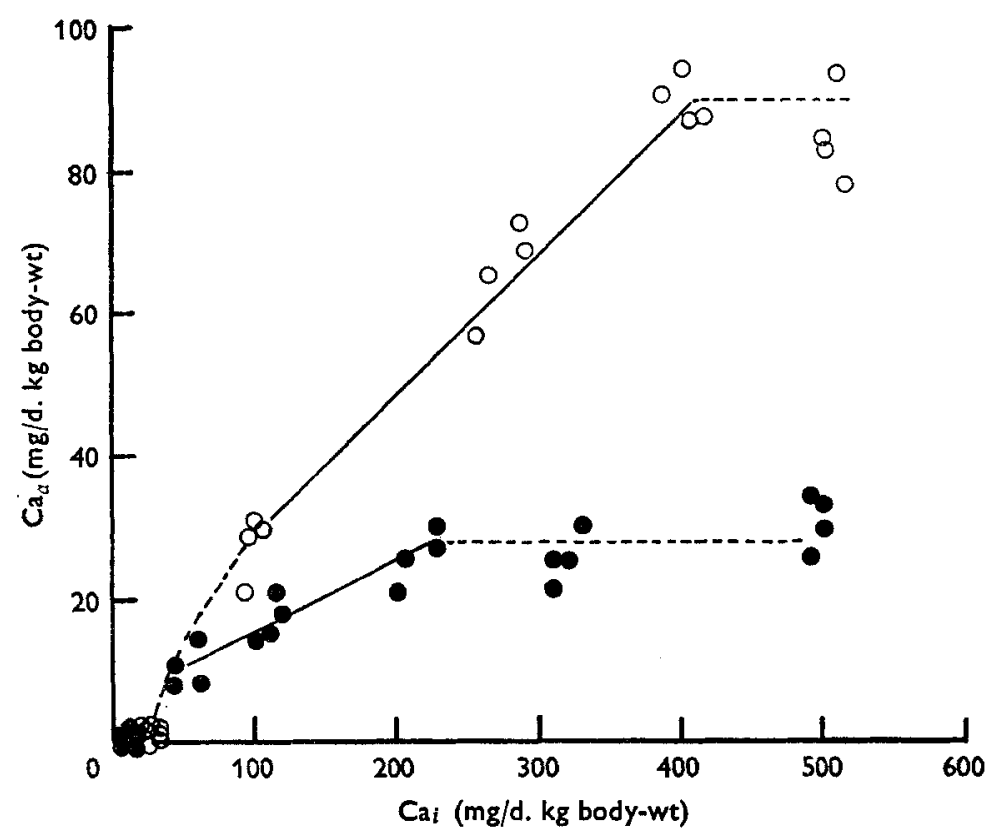

Fig. I. Relationship between calcium intake $\left(\mathrm{Ca}_{i}\right)$ and $\mathrm{Ca}$ absorption $\left(\mathrm{Ca}_{a}\right)$ for wethers. (O), Young animals; $\mathrm{Ca}_{a}=8.4+0.2 \mathrm{Ca}_{i}$. (O), Mature animals; $\mathrm{Ca}_{a}=6.0+0.1 \mathrm{Ca}_{i}$. Animals were given a low-Ca basal diet supplemented with increasing amounts of $\mathrm{Ca}$ and $\mathrm{P}$ (Ca:P about $\mathrm{I}^{\prime} 5$ for higher $\mathrm{Ca}$ intakes). Each level of $\mathrm{Ca}$ intake was maintained for $\mathrm{I} 2 \mathrm{~d}$ and measurements were made from day 5 to day 12 , followed by $18 \mathrm{~d}$ on the low-Ca basal diet alone. For experimental details, see Table 1 and pp. 312-3.

until absorption reached a maximum (Fig. 2) and the following regression equation, in which values were expressed as $\mathrm{mg} / \mathrm{d}$ per $\mathrm{kg}$ body-weight, was calculated:

$$
\mathrm{P}_{a}=-10.9+0.33 \mathrm{P}_{i}
$$

where $\mathrm{P}_{a}$ and $\mathrm{P}_{i}$ are the apparent $\mathrm{P}$ absorption and $\mathrm{P}$ intake respectively.

Average maximum absorption of $\mathbf{P}$ for young animals (1or $\mathrm{mg} / \mathrm{d}$ per $\mathrm{kg}$ bodyweight) was much higher than that for mature animals ( $45 \mathrm{mg} / \mathrm{d}$ per kg body-weight) and occurred at a much higher $\mathrm{P}$ intake. The variation in the rate of $\mathrm{P}$ absorption, which was considerable, particularly at the higher $\mathrm{P}$ intakes, appeared to be associated with variations in urinary $\mathrm{P}$ excretion.

Endogenous excretion of $\mathrm{Ca}$ and $P$. Excretion of $\mathrm{Ca}$ in the urine and into the intestine (faecal endogenous $\mathrm{Ca}$ ) was not significantly altered in these experiments but values for faecal endogenous $\mathrm{Ca}$ were lower than those reported for $\mathrm{Ca}$-replete animals (Braithwaite \& Riazuddin, I97I). It has recently been shown, however, that a gradual decrease in faecal endogenous excretion occurs as animals become adapted to Cadeficient diets (Braithwaite, 1974). As a result of the decreased rates of endogenous excretion, maintenance requirements for $\mathrm{Ca}$ (i.e. the $\mathrm{Ca}$ required to replace endogenous losses into urine and intestine) were lower for $\mathrm{Ca}$-deficient animals than for Ca-replete animals (see Braithwaite $\&$ Riazuddin, r97r).

Excretion of $\mathrm{P}$ in the urine varied considerably with changes in intake. It was high 


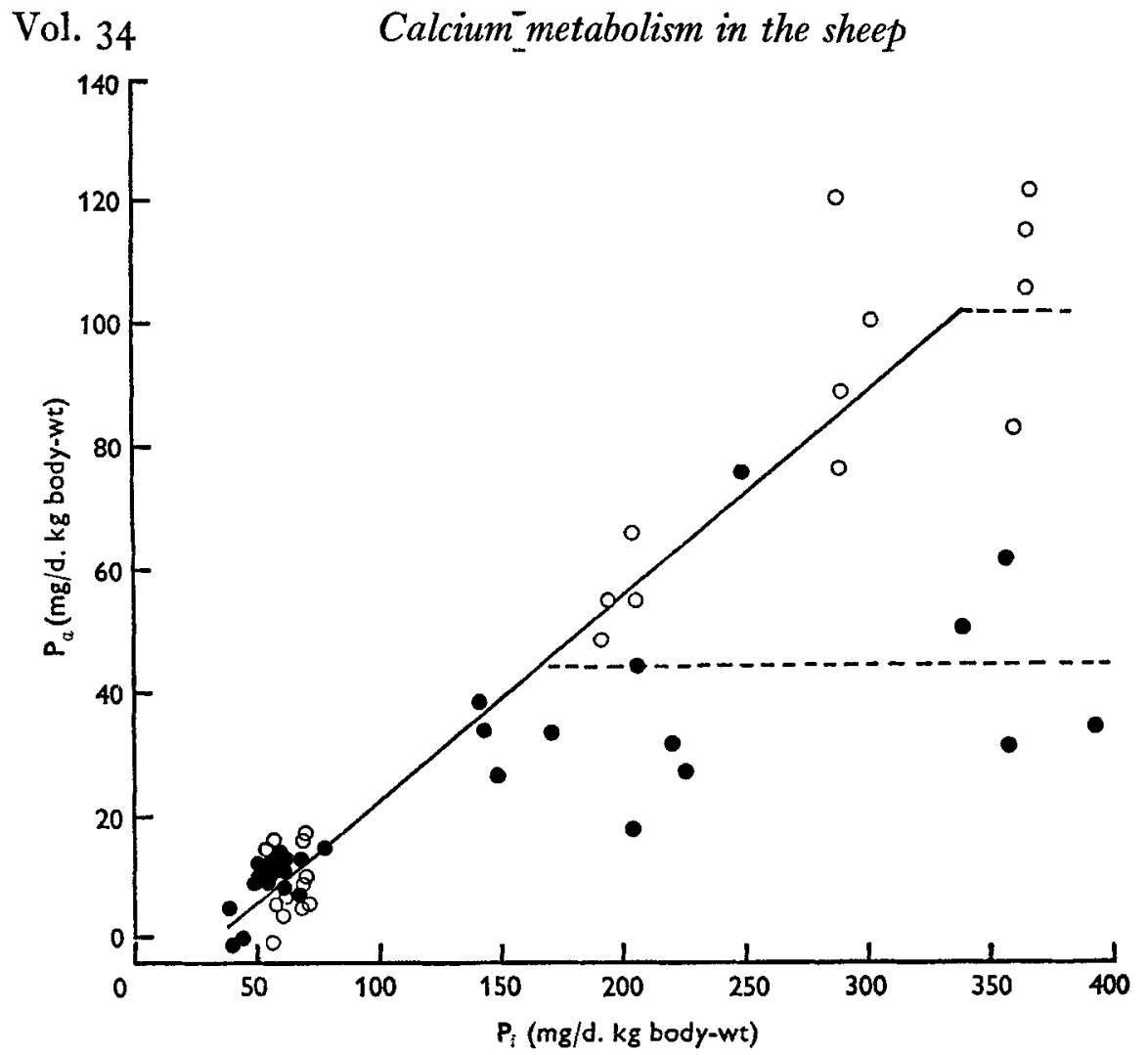

Fig. 2. Relationship between phosphorus intake $\left(P_{i}\right)$ and apparent $P$ absorption $\left(P_{a}\right)$ for young $(O)$ and for mature (O) wethers; $P_{a}=-10.9+0.33 P_{i}$. Animals were given a low-Ca basal diet supplemented with increasing amounts of $\mathrm{Ca}$ and $\mathrm{P}$ (Ca:P about ${ }_{1} \cdot 5$ for higher $\mathrm{Ca}$ intakes). Each level of $\mathrm{Ca}$ intake was maintained for $\mathrm{r} 2 \mathrm{~d}$ and measurements were made from day 5 to day 12 , followed by $18 \mathrm{~d}$ on the low-Ca basal diet alone. For experimental details, see Table I and pp. $312-3$.

for both groups of animals given the Ca-deficient diet, then decreased markedly as the $\mathrm{Ca}$ intake was initially increased (the $\mathrm{P}$ intake remaining constant) and finally increased again as the dietary levels of both $\mathrm{Ca}$ and $\mathrm{P}$ increased. The initial decrease in urinary excretion rate was not related to $\mathbf{P}$ intake, nor to apparent $\mathbf{P}$ absorption, but did appear to be inversely related to the rate of $\mathrm{Ca}$ retention (Fig. 3 ). The subsequent increase in excretion was then directly related $(P<0.00 \mathrm{I})$ to increased $\mathrm{P}$ absorption (Fig. 4). The following regression equations, in which values were expressed as $\mathrm{mg} / \mathrm{d}$ per $\mathrm{kg}$ body-weight, were calculated:

$$
\begin{gathered}
\text { young animals, } \mathrm{P}_{u}=-20.9+0.63 \mathrm{P}_{a} ; \\
\text { mature animals, } \mathrm{P}_{u}=-8.8+0.76 \mathrm{P}_{a} ;
\end{gathered}
$$

where $\mathrm{P}_{u}$ and $\mathrm{P}_{a}$ are the urinary $\mathrm{P}$ and apparent $\mathrm{P}$ absorption respectively.

Retention of $C a$ and $P$. Both groups of animals lost considerable amounts of body $\mathrm{Ca}$ when receiving the Ca-deficient diet (Tables 2, 3). Losses of $\mathrm{P}$ also occurred, particularly in young animals, although the $\mathrm{P}$ intake was adequate. Increased intakes of $\mathrm{Ca}$ and $\mathrm{P}$ then resulted in increased retention for both elements until maximum 


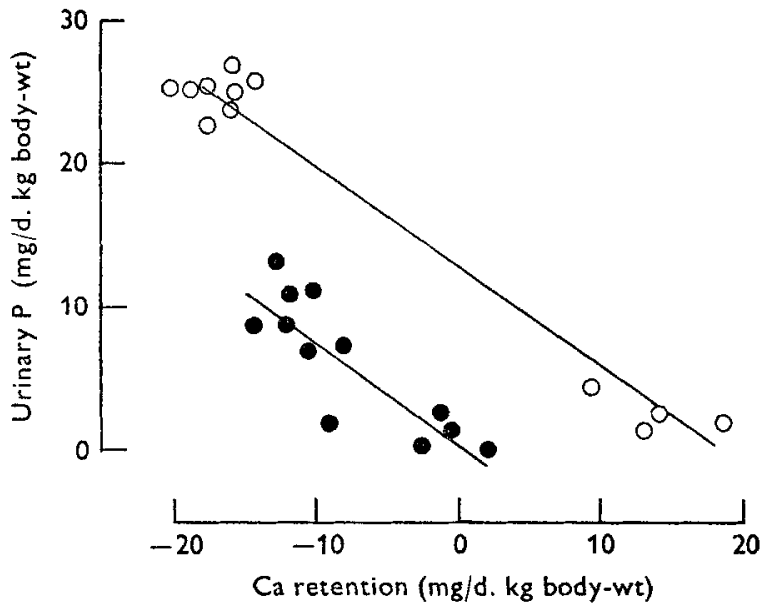

Fig. 3. Relationship between calcium retention and urinary excretion of phosphorus for young $(O)$ and mature $(O)$ wethers given a low-Ca basal diet supplemented with increasing amounts of $\mathrm{Ca}$ and $\mathrm{P}$ (Ca: $\mathrm{P}$ about $\mathrm{I} \cdot 5$ for higher $\mathrm{Ca}$ intakes). Each level of $\mathrm{Ca}$ intake was maintained for $\mathrm{I} 2 \mathrm{~d}$ and measurements were made from day 5 to day $\mathrm{I} 2$, followed by $18 \mathrm{~d}$ on the low-Ca basal diet alone. For experimental details, see Table $I$ and pp. 312-3.

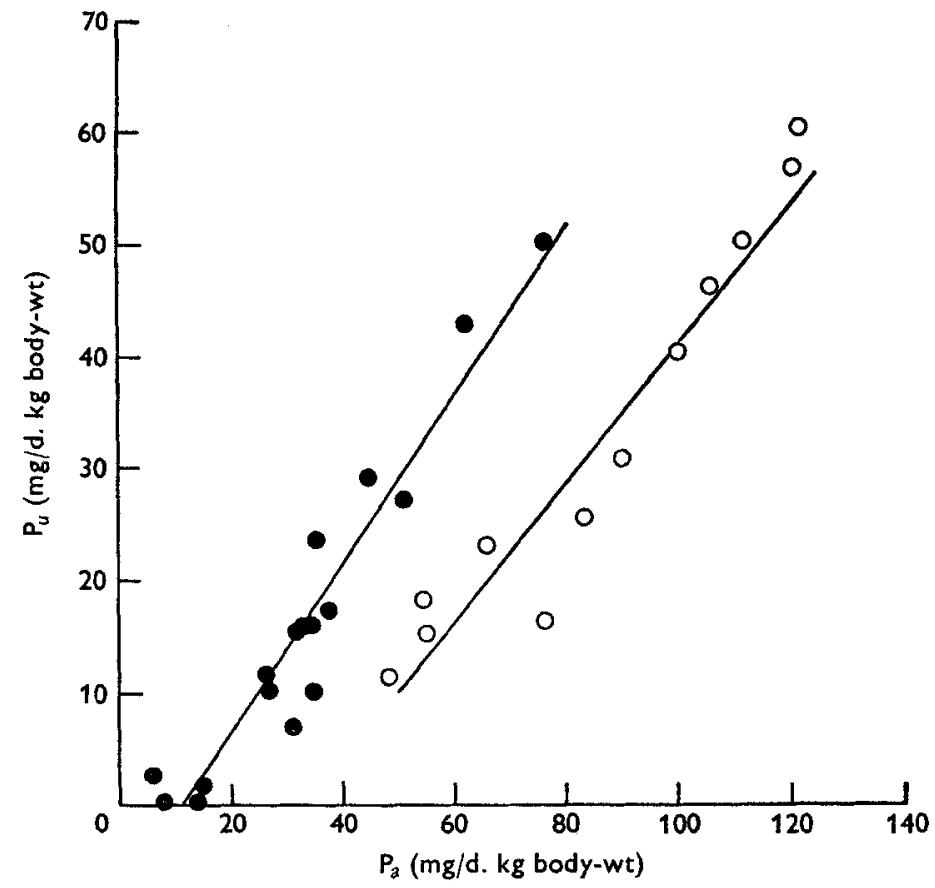

Fig. 4. Relationship between apparent absorption of phosphorus $\left(P_{a}\right)$ and urinary $\mathrm{P}\left(\mathrm{P}_{u}\right)$. (O), Young wethers; $P_{u}=-20.9+0.63 P_{a}$. (O), Mature wethers; $P_{u}=-8.8+0.76 P_{\alpha}$. Animals were given a low-Ca basal diet supplemented with increasing amounts of $\mathrm{Ca}$ and $\mathrm{P}$ (Ca: $\mathrm{P}$ about $\mathrm{I} \cdot 5$ for higher $\mathrm{Ca}$ intakes). Each level of $\mathrm{Ca}$ intake was maintained for $\mathrm{I} 2 \mathrm{~d}$ and measurements were made from day 5 to day $\mathrm{r} 2$, followed by $18 \mathrm{~d}$ on the low-Ca basal diet alone. For experimental details, see Table 1 and pp. 312-3. 


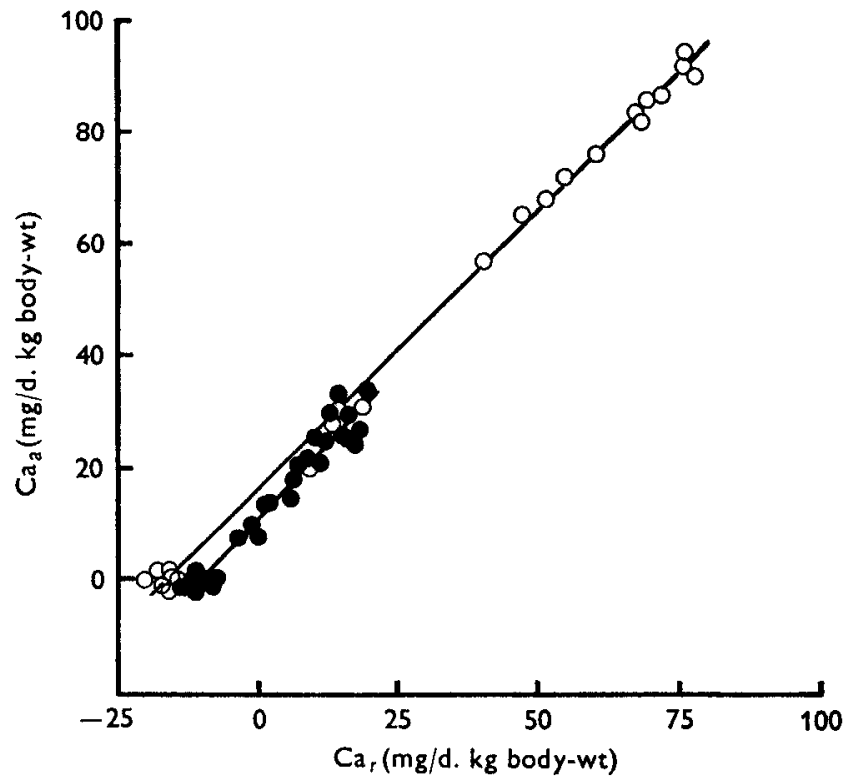

Fig. 5. Relationship between calcium retention $\left(\mathrm{Ca}_{r}\right)$ and $\mathrm{Ca}$ absorption $\left(\mathrm{Ca}_{a}\right)$. (O), Young wethers; $\mathrm{Ca}_{a}=16 \cdot 2+1 \cdot \circ \mathrm{Ca}_{r}$. (०), Mature wethers; $\mathrm{Ca}_{a}=\mathrm{II} \cdot 6+1 \cdot 1 \mathrm{Ca}_{r}$. Animals were given a low-Ca basal diet supplemented with increasing amounts of $\mathrm{Ca}$ and $\mathrm{P}(\mathrm{Ca}: \mathrm{P}$ about $\mathrm{I}^{\cdot} \mathbf{5}$ for higher $\mathrm{Ca}$ intakes). Each level of $\mathrm{Ca}$ intake was maintained for $\mathbf{I} \mathbf{~} \mathrm{d}$ and measurements were made from day 5 to day 12 , followed by $18 \mathrm{~d}$ on the low-Ca basal diet alone. For experimental details, see Table 1 and pp. 312-3.

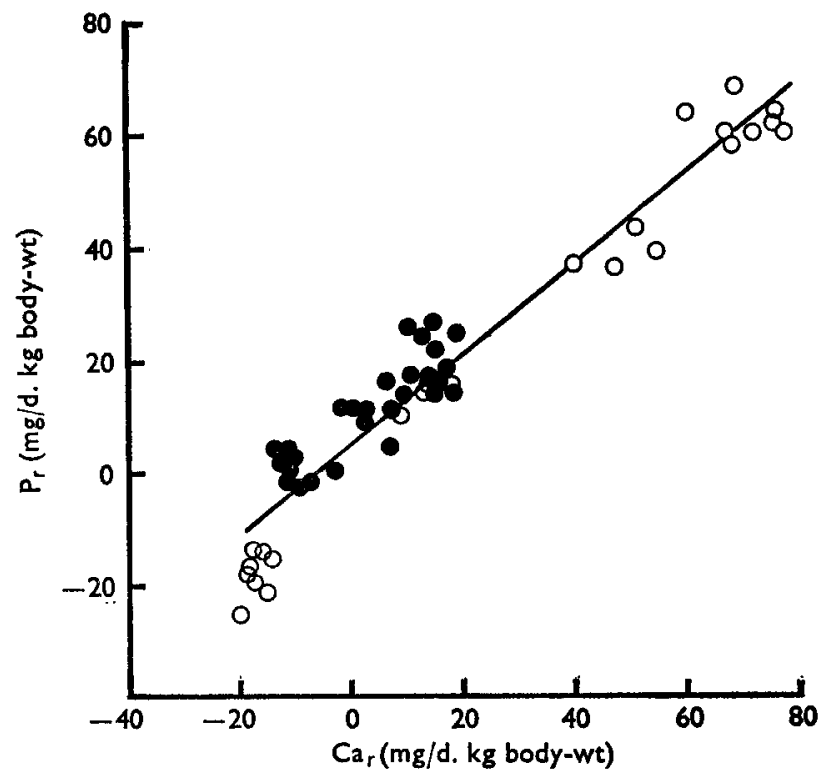

Fig. 6. Relationship between calcium retention $\left(\mathrm{Ca}_{r}\right)$ and phosphorus retention $\left(\mathrm{P}_{r}\right)$ for young (O) and mature (O) wethers; $\mathrm{P}_{r}=4.8+0.8 \mathrm{Ca}_{r}$. Animals were given a low-Ca basal diet supplemented with increasing amounts of $\mathrm{Ca}$ and $\mathrm{P}$ (Ca:P about $\mathrm{I}_{5} \cdot \mathrm{for}$ higher $\mathrm{Ca}$ intakes). Each level of $\mathrm{Ca}$ intake was maintained for $\mathrm{I} 2 \mathrm{~d}$ and measurements were made from day 5 to day I 2 , followed by $18 \mathrm{~d}$ on the low-Ca basal diet alone. For experimental details, see Table I and pp. 3 I $2-3$. 


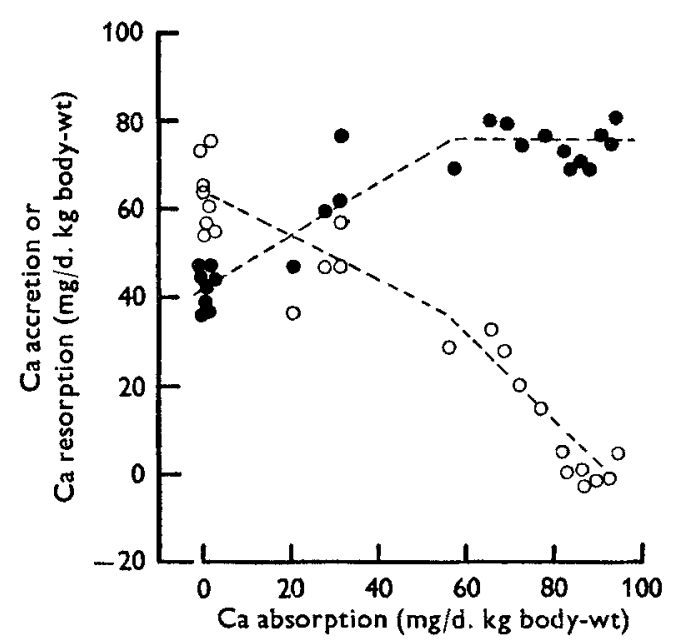

Fig. 7

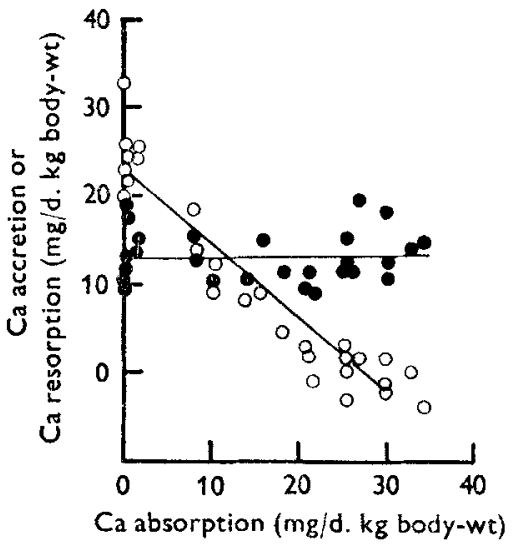

Fig. 8

Fig. 7. Relationship between accretion of calcium into bone ( $O$ ), resorption of Ca from bone (O) and $\mathrm{Ca}$ absorption for young wethers given a low-Ca basal diet supplemented with increasing amounts of $\mathrm{Ca}$ and $\mathrm{P}$ (Ca:P about $\mathrm{i} \cdot 5$ for higher $\mathrm{Ca}$ intakes). Each level of $\mathrm{Ca}$ intake was maintained for $12 \mathrm{~d}$ and measurements were made from day 5 to day 12 , followed by $18 \mathrm{~d}$ on the low-Ca basal diet. For experimental details, see Table 1 and pp. 312-3.

Fig. 8. Relationship between accretion of calcium into bone ( $\Theta$ ), resorption of Ca from bone (O) and $\mathrm{Ca}$ absorption for mature wethers given a low-Ca basal diet supplemented with increasing amounts of $\mathrm{Ca}$ and $\mathrm{P}$ (Ca:P about $\mathrm{I} \cdot 5$ for higher $\mathrm{Ca}$ intakes). Each level of $\mathrm{Ca}$ intake was maintained for $12 \mathrm{~d}$ and measurements were made from day 5 to day 12 , followed by I $8 \mathrm{~d}$ on the low-Ca basal diet. For experimental details, see Table $\mathrm{I}$ and pp. 312-3.

retention was reached. The maximum rate of retention of $\mathrm{Ca}$ for mature animals ( $14 \mathrm{mg} / \mathrm{d}$ per $\mathrm{kg}$ body-weight) was considerably lower than that for young animals ( $71 \mathrm{mg} / \mathrm{d}$ per $\mathrm{kg}$ body-weight) and occurred at a much lower Ca intake $(200 \mathrm{mg} / \mathrm{d}$ per $\mathrm{kg}$ body-weight compared with $400 \mathrm{mg} / \mathrm{d}$ per $\mathrm{kg}$ body-weight for young animals). It was at exactly these same $\mathrm{Ca}$ intakes that maximum $\mathrm{Ca}$ absorption occurred.

Fig. 5 shows that there was a highly significant $(P<0.00 \mathrm{I})$ linear relationship between $\mathrm{Ca}$ absorption and $\mathrm{Ca}$ retention for young and for mature animals, and the following regression equations were calculated:

$$
\begin{aligned}
\text { young animals, } \mathrm{Ca}_{a} & =16 \cdot 2+\mathrm{I} \cdot 0 \mathrm{Ca}_{r} ; \\
\text { mature animals, } \mathrm{Ca}_{a} & =\mathrm{I} \mathbf{1} \cdot 6+\mathrm{I} \cdot \mathrm{I} \mathrm{Ca}_{r} ;
\end{aligned}
$$

where $\mathrm{Ca}_{a}$ and $\mathrm{Ca}_{r}$ are $\mathrm{Ca}$ absorption and $\mathrm{Ca}$ retention (mg/d per $\mathrm{kg}$ body-weight) respectively. These regression equations differed slightly from each other and from that $\left(\mathrm{Ca}_{a}=2 \mathrm{I} \cdot 8+\mathrm{I} \cdot \mathrm{I} \mathrm{Ca}_{r}\right)$ obtained previously for sheep (Braithwaite \& Riazuddin, 1971) but these differences were due to the lower maintenance requirements of the Ca-deficient animals.

Maximum $\mathrm{P}$ retention was also greater for the young ( $6 \mathrm{I} \mathrm{mg} / \mathrm{d}$ per $\mathrm{kg}$ body-weight) than for the mature animals $(19.2 \mathrm{mg} / \mathrm{d}$ per $\mathrm{kg}$ body -weight), and for both groups occurred at about the same time as maximum $\mathrm{Ca}$ retention. Fig. 6 shows there was 


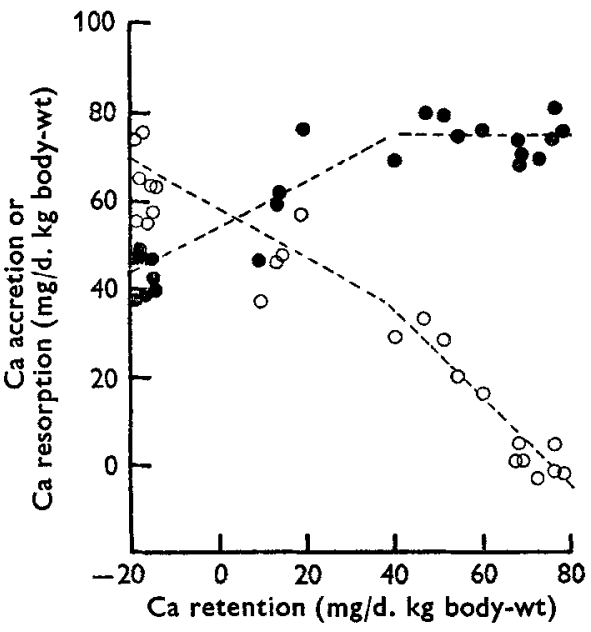

Fig. 9

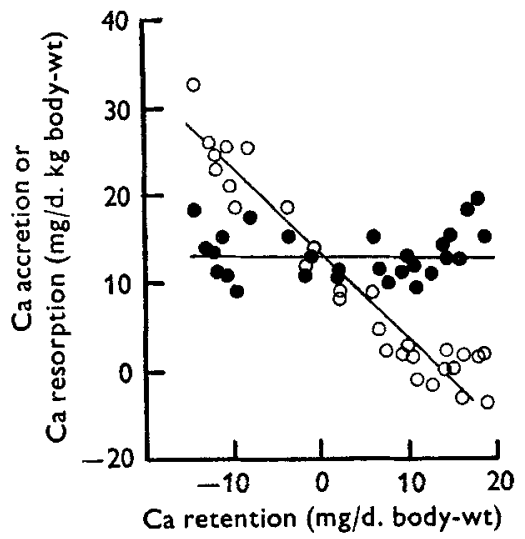

Fig. 10

Fig. 9. Relationship between accretion of calcium into bone ( 9 ), resorption of Ca from bone (O) and $\mathrm{Ca}$ retention for young wethers given a low-Ca basal diet supplemented with increasing amounts of $\mathrm{Ca}$ and $\mathrm{P}(\mathrm{Ca}: \mathrm{P}$ about $\mathrm{I} \cdot 5$ for higher $\mathrm{Ca}$ intakes). Each level of $\mathrm{Ca}$ intake was maintained for $12 \mathrm{~d}$ and measurements were made from day 5 to day 12 , followed by $18 \mathrm{~d}$ on the low-Ca basal diet. For experimental details, see Table 1 and pp. 312-3.

Fig. Io. Relationship between accretion of calcium into bone (O), resorption of Ca from bone (O) and $\mathrm{Ca}$ retention for mature wethers given a low-Ca basal diet supplemented with increasing amounts of $\mathrm{Ca}$ and $\mathrm{P}$ (Ca:P about $\mathrm{I} \cdot 5$ for higher $\mathrm{Ca}$ intakes). Each level of $\mathrm{Ca}$ intake was maintained for $12 \mathrm{~d}$ and measurements were made from day 5 to day 12 , followed by $18 \mathrm{~d}$ on the low-Ca basal diet. For experimental details, see Table $\mathrm{I}$ and pp. 312-3.

a highly significant $(P<0.001)$ linear relationship between $\mathrm{Ca}$ retention and $\mathrm{P}$ retention. From the regression equation:

$$
\mathrm{P}_{r}=4.8+0.8 \mathrm{Ca}_{r}
$$

where $\mathrm{P}_{r}$ and $\mathrm{Ca}_{r}$ are $\mathrm{P}$ and $\mathrm{Ca}$ retention (mg/d per kg body-weight) respectively, it was calculated that the $\mathrm{Ca}: \mathrm{P}$ retention ratio for these $\mathrm{Ca}$-deficient animals was $\mathrm{I} \cdot 25: \mathrm{r}$. This compares with a Ca:P ratio of $\mathrm{r} \cdot 8$ taken by the authors of The Nutrient Requirements of Farm Livestock (Agricultural Research Council, 1965) as corresponding to the proportion of $\mathrm{Ca}$ and $\mathrm{P}$ needed by sheep for whole body growth.

Skeletal metabolism. As previously reported (Braithwaite \& Riazuddin, 1971), bone turnover was considerably lower for the mature than for the young animals.

The relationship between $\mathrm{Ca}$ absorption and bone turnover for young and mature animals is shown in Figs. 7 and 8. With the Ca-deficient diet $\mathrm{Ca}$ absorption was low and the rate of resorption of $\mathrm{Ca}$ from bone was higher than the rate of accretion of $\mathrm{Ca}$ into bone. As the $\mathrm{Ca}$ intake was increased, more $\mathrm{Ca}$ was absorbed, and the rate of bone resorption decreased until at maximum absorption it ceased altogether. Meanwhile the rate of bone accretion increased initially for the young animals but remained constant for the mature animals.

Figs. 9 and to show the relationship between $\mathrm{Ca}$ retention and bone turnover for young and for mature animals. Whereas, with the $\mathrm{Ca}$-deficient diet, a higher rate of bone resorption than of bone accretion resulted in the mobilization of skeletal stores 
of $\mathrm{Ca}$, at high rates of $\mathrm{Ca}$ absorption a lower rate of bone resorption than of bone accretion enabled skeletal stores of $\mathrm{Ca}$ to be replenished. Maximum retention of $\mathrm{Ca}$ for both the young and mature animals was reached when the rate of bone resorption became zero and was approximately equal to the rate of bone accretion (see also Tables 2 and 3 ).

Exchangeable $\mathrm{Ca}$ pools. For the mature Ca-deficient animals neither the rapidly exchangeable $\mathrm{Ca}$ pool, nor the slowly exchangeable $\mathrm{Ca}$ pool for bone were significantly altered by changes in $\mathrm{Ca}$ intake (Table 3). For young animals the rapidly exchangeable $\mathrm{Ca}$ pool was also unaltered but the size of the slowly exchangeable pool for bone increased significantly as the $\mathrm{Ca}$ intake was initially increased (Table 2). The size of the slowly exchangeable $\mathrm{Ca}$ pool for bone has been found to be directly related to the rate of accretion of $\mathrm{Ca}$ into bone for sheep of different ages and breeds (Braithwaite \& Riazuddin, I97I). Its increase in size with increased Ca intake, therefore, was probably only a consequence of the increased rate of accretion of $\mathrm{Ca}$ into bone.

\section{DISCUSSION}

Relationship between $\mathrm{Ca}$ absorption, $\mathrm{Ca}$ retention and bone metabolism. Although skeletal requirements for $\mathrm{Ca}$ must have been high for both young and mature animals, the results indicated that the young $\mathrm{Ca}$-deficient animals absorbed $\mathrm{Ca}$ in much greater amounts and with a higher efficiency than did the Ca-deficient mature animals.

It is interesting that no absorption of $\mathrm{Ca}$ occurred in either group of animals at the lowest level of dietary intake. At this level of intake the $\mathrm{Ca}$ was present mainly as a constituent of the straw (see Table $r$ ) in which it may be lightly bound, and the $\mathrm{P}$ intake was relatively high (Ca:P ratio, $1: 2 \cdot 5)$ which may also have resulted in a reduced availability of $\mathrm{Ca}$. Furthermore, since $\mathrm{Ca}$-binding substances have been found in the contents of the small intestine (Smith \& McAllan, 1966; Smith, 1969) it seems likely that at the low $\mathrm{Ca}$ intake, all intestinal $\mathrm{Ca}$ was present in an unavailable form.

The finding that both $\mathrm{Ca}$ absorption and $\mathrm{Ca}$ retention became maximal at the same dietary $\mathrm{Ca}$ intake suggests that only one of these processes may have reached a true maximal rate and that the other was limited as a consequence.

Since $99 \%$ of the body $\mathrm{Ca}$ is present in the skeleton, total body retention of $\mathrm{Ca}$ can be regarded as being the same as skeletal retention, which is equal to the difference between the rate of accretion of $\mathrm{Ca}$ into bone and the rate of resorption of $\mathrm{Ca}$ from bone. In the present experiments, the rate of bone accretion, apart from an initial increase for young animals, remained remarkably constant, and at higher intakes increased retention was achieved entirely by decreased bone resorption. Maximum body retention of $\mathrm{Ca}$ occurred, for all animals, just as bone resorption became zero and, as would then be expected, was approximately equal to the rate of bone accretion. 'These findings contrast with those of Bronner (1967), who calculated $\mathrm{Ca}$ retention rates greatly in excess of bone accretion rates for growing rats receiving high $\mathrm{Ca}$ intakes. His results led him to conclude that an alternative to compartmental analysis might have to be sought. The possibility, however, that the simple two-compartment model, on which his calculations were based, was inadequate 
cannot be ruled out and the present results, calculated from a more complex model, suggest that compartmental analysis does give valid results for the sheep.

The finding that maximum retention of $\mathrm{Ca}$ was equal to the rate of accretion of $\mathrm{Ca}$ into bone and coincided with the cessation of bone resorption provides strong evidence that maximum rates of $\mathrm{Ca}$ retention measured in these experiments were in fact true maximum rates. This leads to the suggestion that maximum rates of absorption measured may not be true maximum rates but rather that $\mathrm{Ca}$ absorption became regulated by homoeostatic mechanisms at a level just sufficient to allow maximum retention.

The finding that maximum retention of $\mathrm{Ca}$ is equal to the rate of accretion of $\mathrm{Ca}$ into bone also explains the differences obtained for Ca metabolism of young and mature Ca-deficient animals. Many of the processes of Ca metabolism, including bone accretion, have been shown to decrease markedly in intensity with increasing age (Braithwaite $\&$ Riazuddin, 197I). Older animals, therefore, have a low maximum rate of $\mathrm{Ca}$ retention and, irrespective of their $\mathrm{Ca}$ requirements, high $\mathrm{Ca}$ intakes are of no benefit to them. Recently it has been shown that the administration of oestrogen or growth hormone to nearly mature wether sheep enhanced growth and reversed the normal effects of age on Ca metabolism (Braithwaite et al. 1972; Braithwaite, 1975). For these older animals, a stimulation of the rate of accretion of $\mathrm{Ca}$ into bone was accompanied by an increased ability to absorb and retain $\mathrm{Ca}$.

A relationship between the rate of accretion of $\mathrm{Ca}$ into bone and maximum $\mathrm{Ca}$ retention also suggests a possible reason for the increased rates of bone accretion obtained for mature ewes during pregnancy and lactation (Braithwaite et al. 1969, 1970). These animals lost up to $2 \mathrm{~g} \mathrm{Ca} / \mathrm{kg}$ body-weight during late pregnancy and early lactation, when demands for $\mathrm{Ca}$ were high, but then replaced this lost $\mathrm{Ca}$ in late lactation and in the following dry period, when demands were reduced. Bone accretion rates, which in early pregnancy were about normal $(8 \mathrm{mg} / \mathrm{d}$ per $\mathrm{kg}$ body-weight) for older animals (Braithwaite \& Riazuddin, 1971) increased approximately threefold ( $30 \mathrm{mg} / \mathrm{d}$ per $\mathrm{kg}$ body-weight) during lactation. If bone accretion rates had remained at the initial low level and they do determine maximum retention, animals would have been unable to replace the $\mathrm{Ca}$ losses of one reproductive cycle before the onset of the next. The increase in accretion rate during lactation, however, ensured that lost reserves were replaced relatively quickly.

The initial increase in rate of bone accretion with increased $\mathrm{Ca}$ intake for young Ca-deficient animals but not for mature animals suggested that young animals are able to adapt to low-Ca diets by decreasing bone accretion and that this ability is lost at maturity. Certainly decreased rates of bone accretion have been reported for young Ca-deficient rats (Stauffer, Baylink, Wergedal \& Rich, 1973), but similar decreases were not found for mature $\mathrm{Ca}$-deficient sheep (Braithwaite, I974).

Relationship between $\mathrm{Ca}$ and $\mathrm{P}$ metabolism. Retention of $\mathrm{Ca}$ was directly related to $\mathrm{Ca}$ absorption but $\mathrm{P}$ retention was more closely related to $\mathrm{Ca}$ retention than to apparent $\mathrm{P}$ absorption; the $\mathrm{Ca}: \mathrm{P}$ retention ratio remained constant although there were variations in the $\mathrm{Ca}: \mathrm{P}$ absorption ratio. Results indicated, therefore, that for these $\mathrm{Ca}$-deficient animals $\mathrm{P}$ retention was controlled by the rate of $\mathrm{Ca}$ retention. 
The initial decrease in urinary $\mathrm{P}$ excretion with increased $\mathrm{Ca}$ intake appeared to be related to changes in $\mathrm{Ca}$ retention, rather than to changes in $\mathrm{P}$ intake, which remained constant, or to apparent $\mathrm{P}$ absorption, which tended to increase slightly. Decreased urinary excretion of $\mathrm{P}$ with increased $\mathrm{Ca}$ intake has also been reported for rats (Clark \& Rivera-Cordero, 1973), but for these animals the decrease was accompanied by a decrease in $\mathrm{P}$ absorption and an increase in faecal endogenous excretion of $\mathrm{P}$. In the present experiments, the initial decrease in $\mathrm{P}$ excretion probably resulted from the decreased rate of bone resorption. With the Ca-deficient diet, the high rate of bone resorption needed to supply maintenance requirements of $\mathrm{Ca}$ must also have resulted in the release of large amounts of bone $\mathrm{P}$. Since animals were already absorbing more than sufficient $P$ for maintenance, the excess was presumably excreted in the urine. When the $\mathrm{Ca}$ intake was increased, more $\mathrm{Ca}$ was absorbed and bone resorption decreased. The supply of $\mathrm{P}$ from bone was reduced and urinary excretion of $\mathrm{P}$ decreased.

$\mathrm{Ca}$ and $P$ homoeostasis. Animals made good their maintenance requirements for $\mathrm{Ca}$ when receiving the Ca-deficient diet and replaced their skeletal losses when the dietary $\mathrm{Ca}$ was again plentiful, by altering the relative rates of bone accretion and bone resorption. Although in these experiments, as in those of Braithwaite (1974), bone resorption was the process largely responsible for $\mathrm{Ca}$ homoeostasis, bone accretion appeared to play an important part in the young $\mathrm{Ca}$-deficient animals. Furthermore, at very high $\mathrm{Ca}$ intakes, when the rate of bone resorption was zero and $\mathrm{Ca}$ retention was maximal, $\mathrm{Ca}$ homoeostasis was probably achieved by regulation of $\mathrm{Ca}$ absorption.

$\mathrm{P}$ metabolism was closely linked to $\mathrm{Ca}$ metabolism in these $\mathrm{Ca}$-deficient animals, and results indicated that $\mathrm{P}$ homoeostasis was largely brought about by a control of urinary $\mathrm{P}$ excretion.

The author thanks Dr R. F. Glascock for his advice and encouragement, Miss S. G. Neville and Mr B. Woods for technical assistance, and Mr R. Ellis and Mr A. R. Jones for their care of the experimental animals.

\section{REFERENCES}

Agricultural Research Council (1965). The Nutrient Requirements of Farm Livestock No. 2, Ruminants. London: Agricultural Research Council.

Aubert, J.-P. \& Milhaud, G. (1960). Biochim. biophys. Acta 39, 122.

Braithwaite, G. D. (1974). Br. F. Nutr. 31, 319.

Braithwaite, G. D. (1975). Br. F. Nutr. 33, 309 .

Braithwaite, G. D., Glascock, R. F. \& Riazuddin, Sh. (1969). Br. F. Nutr. 23, 827.

Braithwaite, G. D., Glascock, R. F. \& Riazuddin, Sh. (1970). Br. F. Nutr. 24, 66r.

Braithwaite, G. D., Glascock, R. F. \& Riazuddin, Sh. (1972). Br. F. Nutr. 28, 269.

Braithwaite, G. D. \& Riazuddin, Sh. (1971). Br. F. Nutr. 26, 215.

Bronner, F. (1967). Trans. N.Y. Acad. Sci. ser. ii, 29, 502.

Clark, I. \& Rivera-Cordero, F. (1973). Endocrinology 92, 62.

Fiske, C. H. \& Subbarow, Y. (I925). F. biol. Chem. 66, 375.

Smith, R. H. (I969). Proc. Nutr. Soc. 28, 15 I.

Smith, R. H. \& McAllan, A. B. (1966). Br. F. Nutr. 20, 703.

Stauffer, M., Baylink, D., Wergedal, J. \& Rich, C. (1973). Am. F. Physiol. 225, 269.

Technicon Instruments Corporation (1967). Technicon Method Sheet N-4B. Tarry Town, New York: Technicon Instruments Corporation. 